\title{
A Systems Thinking Approach to Redesigning the Patient Experience to Reduce 30 Day Hospital Readmission
}

\author{
William Flounders, MBA \\ Thomas Jefferson University \\ Justin Gates, MBA \\ Thomas Jefferson University \\ Steven Heffner, MBA \\ Thomas Jefferson University \\ Michael Lawler, BS, RN, MSN, FNP-BC, MBA \\ Thomas Jefferson University \\ Julia Pardini, MBA \\ Thomas Jefferson University \\ Follow this and additional works at: https://jdc.jefferson.edu/jhnj \\ Let us know, how access to this document benefits you
}

\section{Recommended Citation}

Flounders, MBA, William; Gates, MBA, Justin; Heffner, MBA, Steven; Lawler, BS, RN, MSN, FNP-BC, MBA, Michael; Pardini, MBA, Julia; DePrince, RN, BA, CCRN, SCRN, Maureen; and Rosenwasser, MD, MBA, FACS, FAHA, Robert H. (2018) "A Systems Thinking Approach to Redesigning the Patient Experience to Reduce 30 Day Hospital Readmission," JHN Journal: Vol. 13 : Iss. 2 , Article 1.

DOI: https://doi.org/10.29046/JHNJ.013.2.001

Available at: https://jdc.jefferson.edu/jhnj/vol13/iss2/1

This Article is brought to you for free and open access by the Jefferson Digital Commons. The Jefferson Digital Commons is a service of Thomas Jefferson University's Center for Teaching and Learning (CTL). The Commons is a showcase for Jefferson books and journals, peer-reviewed scholarly publications, unique historical collections from the University archives, and teaching tools. The Jefferson Digital Commons allows researchers and interested readers anywhere in the world to learn about and keep up to date with Jefferson scholarship. This article has been accepted for inclusion in JHN Journal by an authorized administrator of the Jefferson Digital Commons. For more information, please contact: JeffersonDigitalCommons@jefferson.edu. 


\section{A Systems Thinking Approach to Redesigning the Patient Experience to Reduce}

30 Day Hospital Readmission

\section{Authors}

William Flounders, MBA; Justin Gates, MBA; Steven Heffner, MBA; Michael Lawler, BS, RN, MSN, FNP-BC, MBA; Julia Pardini, MBA; Maureen DePrince, RN, BA, CCRN, SCRN; and Robert H. Rosenwasser, MD, MBA, FACS, FAHA 


\section{A Systems Thinking Approach to Redesigning the Patient Experience to Reduce 30 Day Hospital Readmission}

William Flounders, MBA; Justin Gates, MBA; Steven Heffner, MBA; Michael J. Lawler BS, RN, MSN, FNP-BC, MBA; Julie Pardini, MBA; Maureen DePrince, RN, BA, CCRN, SCRN; Robert Rosenwasser, MD, MBA, FACS, FAHA

Department of Neurological Surgery, Thomas Jefferson University and Jefferson Hospital for Neuroscience, Philadelphia, Pennsylvania, USA

\section{INTRODUCTION}

The cost of medical care is spiraling out of control, and one of the many reasons is lack of preventative care, poor communication to the patient and primary caregiver(s) both in an inpatient and outpatient setting. There are potentially many reasons for this cost escalation, one of the drivers of this cost is 30 day readmission after a hospitalization and this is what was examined in this analysis.

The purpose of this paper in particular is to share what has been learned using a systems thinking approach to hospital readmissions and the patient experience. It is critical to understand the problems that occurred in the past. In addition, we will explain the methodology utilized and bring awareness to the iterative process. We will also demonstrate a suggested redesigned model.

It is clear that the current system of medical care within the United States is expensive, wasteful and has failed in preventative care and promotion of wellness. Therefore, it is critical to change directions instead of the same paradigm (Old Street to go down Change Boulevard.)

The methodology utilized to dissect the problem was approached by employing the elements of systems thinking; looking at emergent properties, the importance of asking questions, problem dissolution, and listening and additional dialogue with key stakeholders. In addition, constant iteration and communication was important in developing functional models.

\section{Emergent Properties (Figure 1)}

Infeasable parts on their own do not yield the ideal but together they must create a feasible whole. Importance of asking questions is that the right questions must

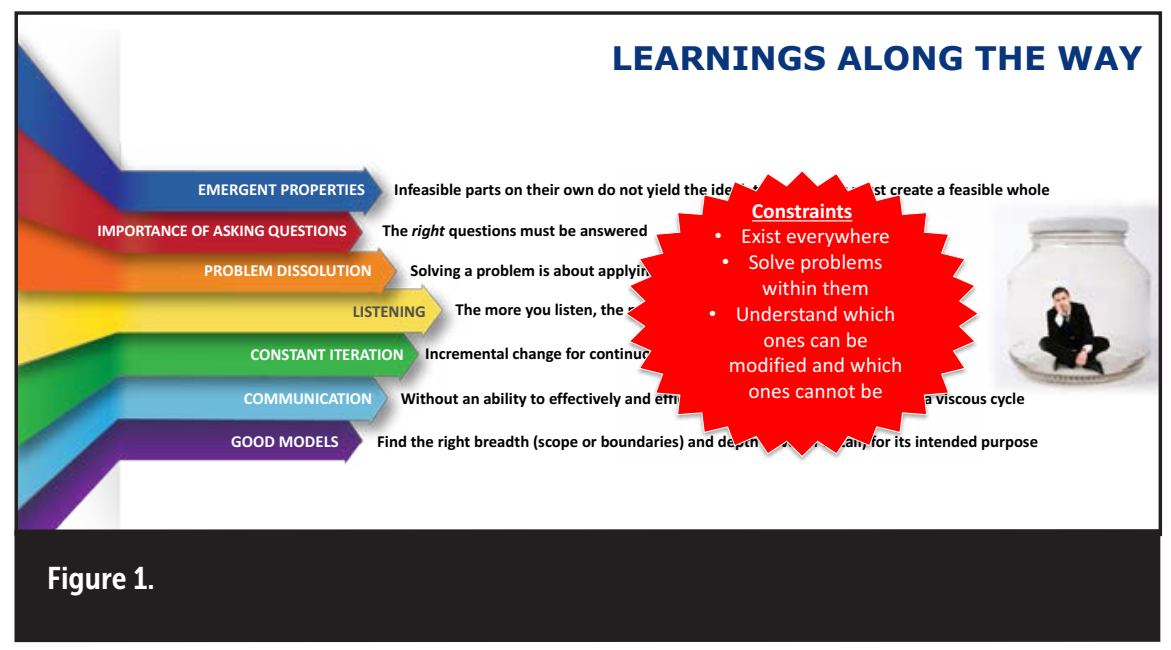

be asked and answered. Problem dissolution is solving the problem about applying redesigned solution to the problem after deconstruction has taken place. Listening, the more one listens, the more one will understand the problems and get to the "why." Constant iteration is essential and involves incremental change for continuous improvement. Communication without the ability to effectively and efficiently communicate, a vicious cycle continues. Good models - find the right breadth (scope and boundaries) and depth and (level of detail) for its intended purpose.

Constraints exist and are universal, but it is essential to solve problems within the constraints and understand which ones can be modified in which ones cannot.

A systems thinking framework involves the agenda, the context, opinions, and mental models in shared learning.

It is important to define the system boundaries and as figure 2 illustrates, new boundaries are created and changed in order to conform to the system.

There is not one correct mix, there are multiple levers to pull which include physician, patient and family unit, payor, policy maker, care delivery team and provider, and the financial aspect of delivering medical care.

It is important to remember the focus and time for review is essential. Currently the healthcare delivery model is in a significant transition and historically the system within the United States has been a volume-based model which is clearly shifting to a value based model. Value is defined as health outcomes divided by the cost of delivering the outcomes and revenue transition. The transition exists where these index curves are changing from volume-based to value-based and is illustrated in figure 3.

Hospital readmissions are a symptom of disease and these make up the "mess" as defined within a systems thinking 

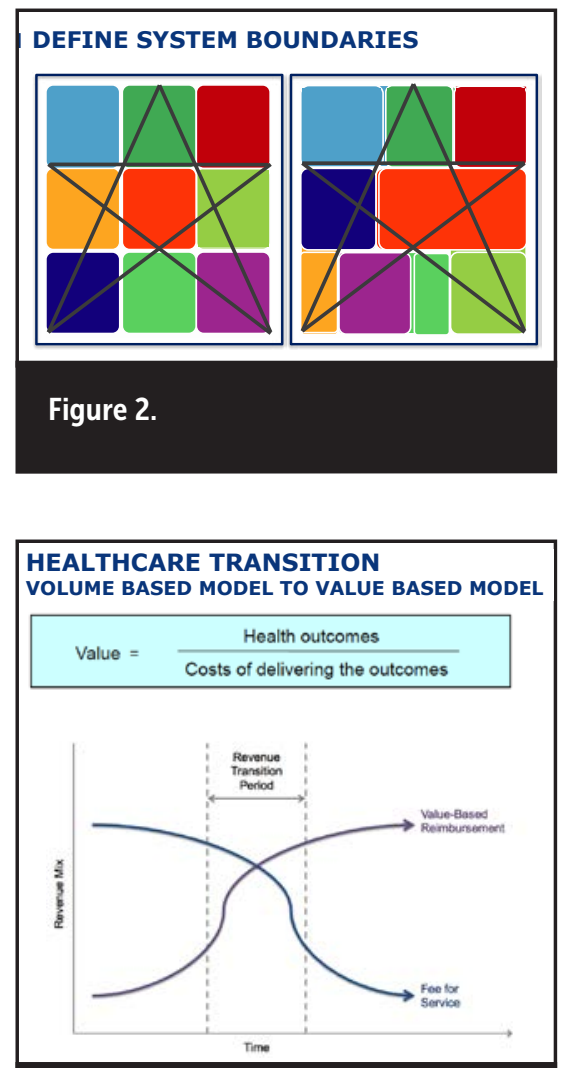

Figure 3.

context. (Ref J. Gharajedaghi). Walter Cronkite, a well-known and respected news journalist 50 years ago indicated that America's healthcare system is neither healthy, caring, nor a system. The impact is enormous and the cost to society of 30-day readmissions are crushing the system. The goal is that savings would be generated by a new paradigm and used for wellness and disease prevention. The project scope and mission in this model was to deconstruct the current system and develop a refined and iterative model to reduce the hospital readmissions for neurovascular events which include hemorrhagic stroke and ruptured intracranial aneurysms, two diagnoses that are extremely costly to the current system (Figure 4).

As alluded to, hospital readmissions are symptom of the disease as figure 5 illustrates. Readmissions account for 24 billion USD in the Medicare program, 8.1 billion USD in privately insured patients, 7.6 billion USD in the Medicaid

\section{HOSPITAL READMISSIONS "SYMPTOM OF THE DISEASE / MESS"}

\section{"America's health care system is neither healthy, caring, nor a system." \\ Walter Cronkite, News Journalist, 50 years ago.}

Impact: Enormous Cost to Society for 30-day readmission

Goal: Savings could be used for wellness and prevention

Project Scope: Neurovascular Events

(Hemorrhagic stroke \& ruptured aneurysm)

\section{Figure 4.}

\section{HOSPITAL READMISSIONS}

Symptom of the "Disease"

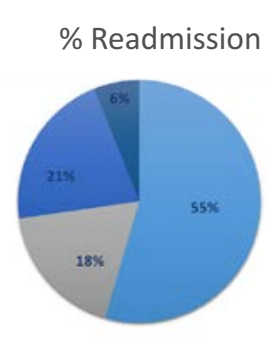
Patient Category
Medicare program
Privately insured Patient
Medicaid Patient
Uninsured Patients

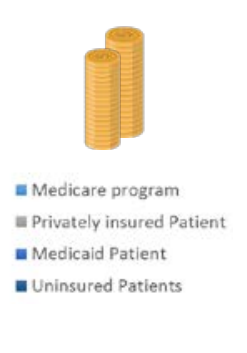

\% Cost (Billion USD)

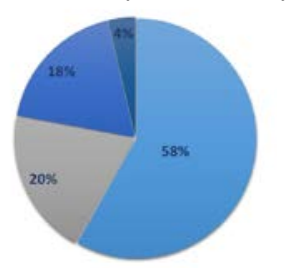

Number readmissions (Million) Cost (Billion USD) $\begin{array}{lll}1.8 & 24 \\ 0.6 & 8.1\end{array}$ $\begin{array}{ll}0.6 & 8.1 \\ 0.7 & 7.6\end{array}$ $\underline{0.2} \quad \underline{1.5}$

\section{Figure 5.}

population and over 1.5 billion USD in uninsured patients. The total number of readmissions in 2016 was 3.3 million for an annual cost of 41.2 billion USD. As the figure 5 illustrates, not only the cost but the percent are largest in the Medicare population.

\section{THE PROBLEM}

In 2012, Center for Medicare Services believed providers with excess readmissions were providing low quality care and the proposed remedy at that time, was financial punishment to the professional and technical components of healthcare delivery. In 2013, there was a $1 \%$ penalty; 2014, a 2\% penalty; in 2015, a 3\% penalty. That is, not only would physicians and hospitals not be paid for care delivered but in addition, a penalty would be paid to CMS, (Center for Medicare Services). In the United States, $82 \%$ of hospitals were affected by this penalty.

The simplified "Map of the Mess" as figure 6 illustrates, includes several vicious cycles that have been identified between the policy maker and misaligned incentives, between the payor and the patient, and between the patient and the policy maker. Avoidable unplanned readmissions are due to many factors including secondary care (such as inadequate or inappropriate rehabilitation) which is suboptimal and the poor communication of the event and post-hospital discharge planning and education and 


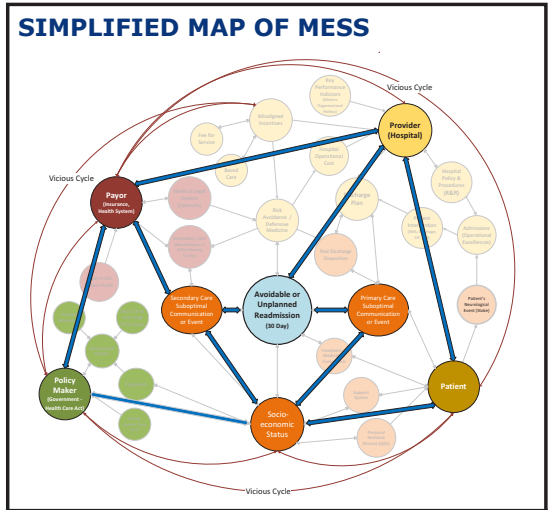

Figure 6.

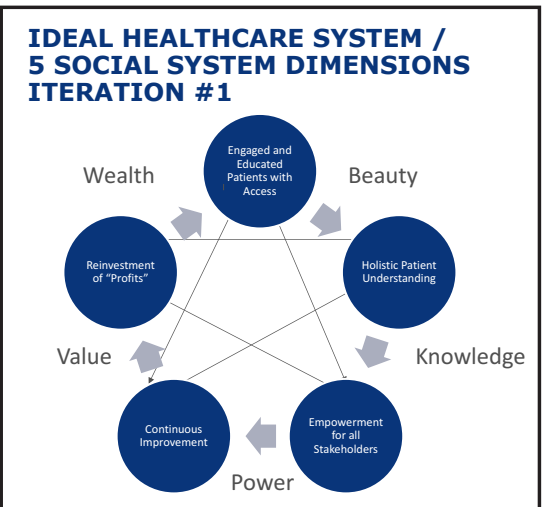

Figure 8.

sub-optimal primary care and communication of the event. This is affected by the socioeconomic status the individual and as the figure 6 illustrates, there are many interconnected variables.

\section{Pathway to Potential Solutions}

A winning healthcare formula starts with solving the right problems plus idealized design. Figure 7 illustrates the timeline which the investigators embarked upon to examine the problem, and to proceed with problem dissolution and reconstruction. On September 27th, there was an introduction meeting with hospital stakeholders. October 20th, the initial "mess" construction began. On November 2nd, interviews with key stakeholders performed by members of the research team. December 3rd, "Map of the Mess" was presented for consideration, criticism, and comment.

\section{TEAM DESIGN TEAM JOURNEY}

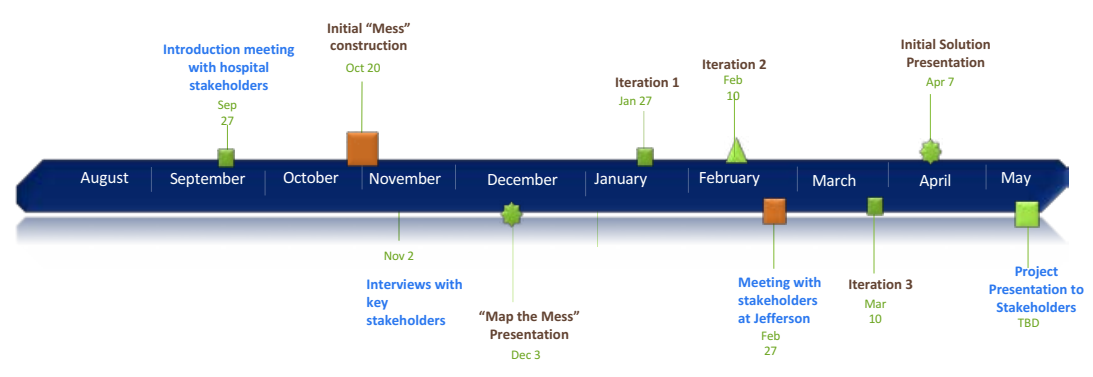

Figure 7.

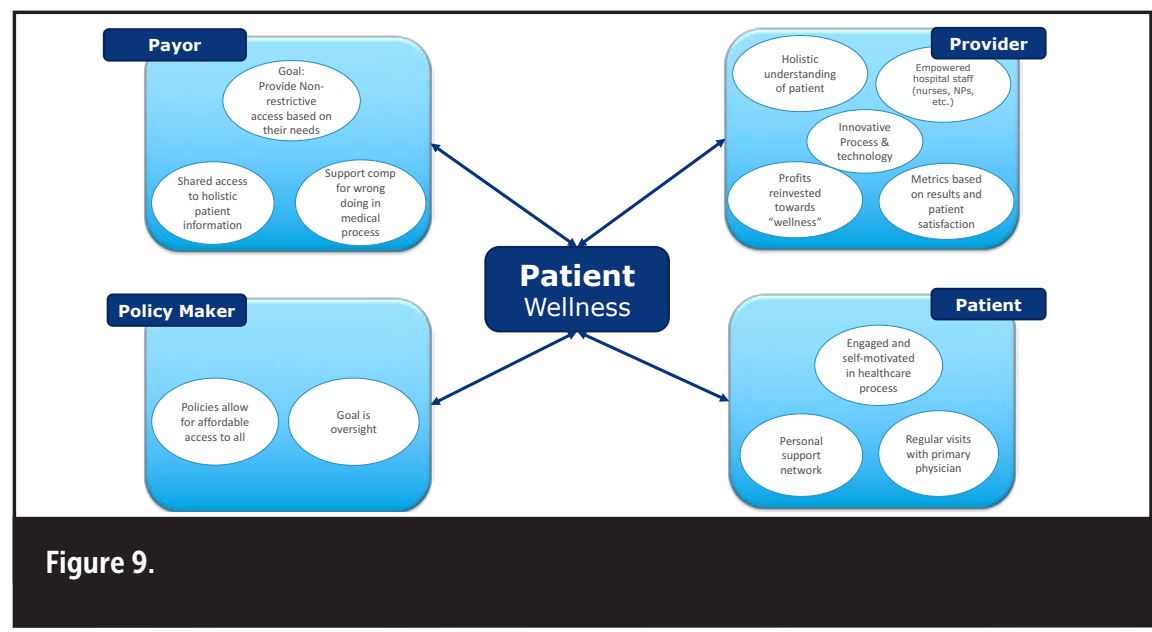

Once that had been accomplished, the 1st iteration was completed on January 27 th, the 2 nd iteration was completed on February 10 th. After the 2 nd iteration, there was a 2nd meeting with hospital stakeholders involved with this project on February 27th. This led to iteration \#3 and on March 10th with the initial solution presentation on April 7th and complete project presentation and recommendations in May of 2017.

The common thread identified in problem dissolution was inefficient and inadequate communication as major drivers of hospital readmission. An additional factor was the significant impact of risk avoidance by healthcare providers influencing behavior and decisions. That is "easiest and safest" decision is to readmit the patient.
Based on these findings, the traditional care process for this subgroup of neurological patients was entirely deconstructed. Design specifications included a primary endpoint of reduction in 30-day readmission, a secondary endpoint of reduced cost to the system and a tertiary endpoint to improve patient outcome.

The ideal healthcare system using systems thinking definitions and methodology involve the 5 social system dimensions including wealth, beauty, knowledge, power, and value. They are illustrated in figure 8 . Patients were engaged and educated, patients with access to information, holistic patient understanding, empowerment for all stakeholders, leading to continuous improvement and reinvestment of profits into wellness, disease 


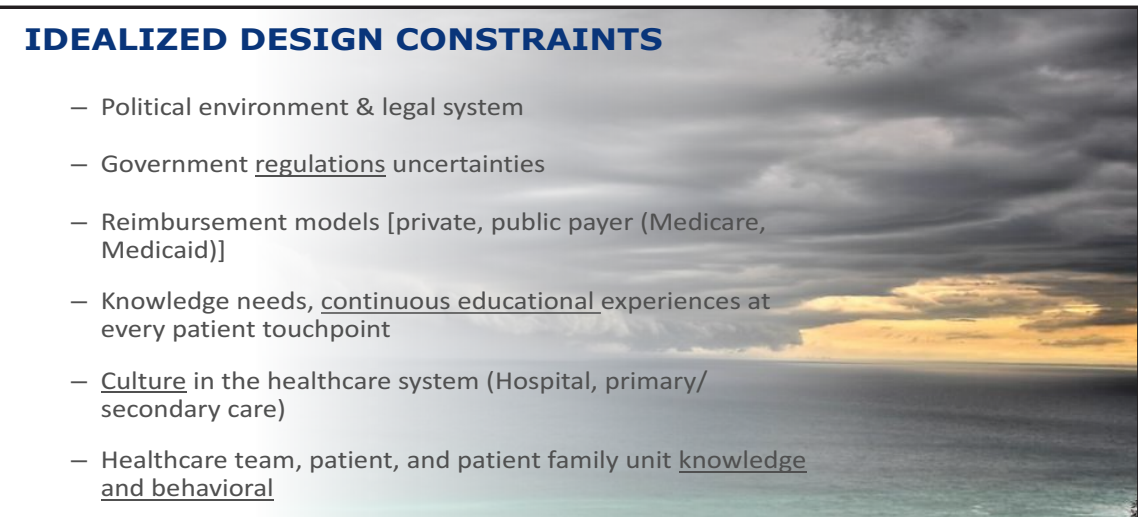

Figure 10.

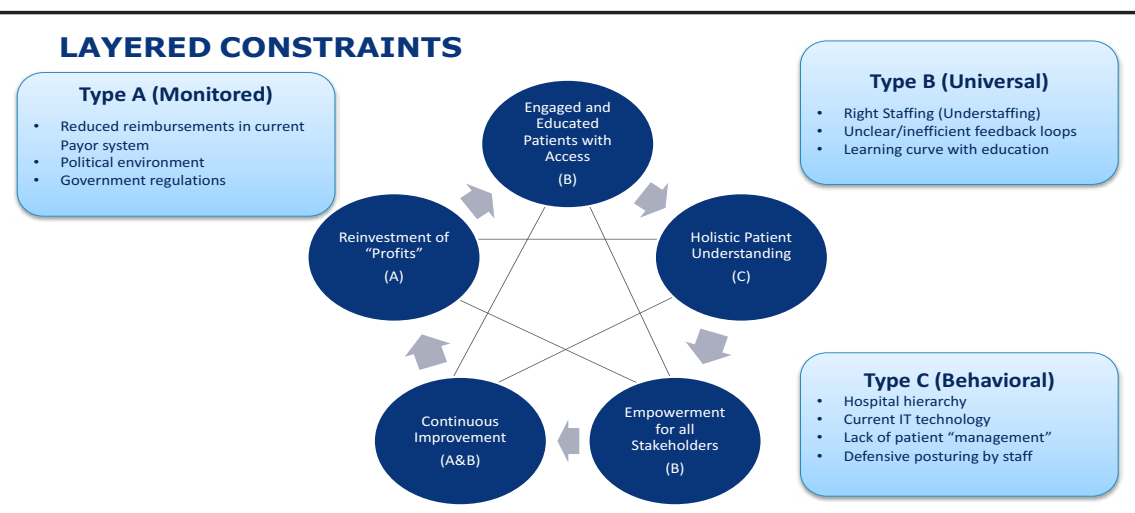

Figure 11.

prevention, education, and improved communication.

The patient wellness involved multiple categories but the 4 areas in particular intersecting are the payor, the policy maker, the provider, and the patient.

Concerning the payor, the goal is to provide nonrestrictive access based on patients' needs, shared access to holistic patient information, and support compensation of financial remuneration for medical errors.

The provider needs to have a holistic understanding of the patient, empowered hospital staff such as nurse practitioners and physician's assistants. There is need for development of innovative process and technologies and profit should/ would be reinvested toward improving wellness. Metrics should also be based
3. Reimbursement models, whether private, public payor such as Medicare or Medicaid.

4. Knowledge needs and continuous educational experiences and every patient touch point in the system.

5. The culture in the healthcare system must be changed, not only within the hospital but in primary and secondary care regarding communication to all stakeholders.

6. Healthcare team, the patient, and the patient's family unit knowledge and behavioral constraints exist and must be dealt with accordingly.

\section{Layered Constraints (Figure 11)}

The layered constraints consist of 3 types. Type A, Type B, and Type C. Type A constraint is a monitored constraint with reduced reimbursements in the current payer system, the political environment and government regulations. Type $B$ are universal constraints such as does a right staffing ratio exist, unclear and inefficient feedback loops and certainly there is a learning curve with education. Type C constraints which are behavioral deal with the hospital hierarchy, the current IT back bone, and lack of patient management. In addition, there is often defensive posturing by the staff which needs to be altered. As the figure 11 illustrates, a reinvestment of profits will lead to engaged and educated patients with access to care and holistic understanding of the patient. This allows empowerment for all stakeholders with continuous improvement and a virtuous cycle is created.

Iteration \#2 involved the 2nd meeting with stakeholders at Thomas Jefferson University Hospital and Jefferson Hospital for Neuroscience (Figure 12). The "Patient/Owner managing team" is Value. Nationally accessible patient history is Knowledge as such would be utilized with an electronic medical record. Physicians and stakeholders should be empowered which is Power along that spectrum. Again, Wealth involves aligning government and payor incentives. Beauty in systems context, is utilizing technology to engage all stakeholders and caregivers to and for the patient. 
Iteration \#3 (Figure 13) was to develop a patient technology platform that provides all previous medical history, real-time interactions from all touch points and suggested and recommended treatment pathways. A single dedicated resource (Patient Navigator System) for all patients that move through the system is critical and creates a "community of care network".

The path to a virtuous cycle involves understanding the mess, dissolution and multiple iterations and finally idealized design. This is illustrated in figure 14. The vicious cycles need to be removed and the key components of the provider which involves hospital, suboptimal primary care and secondary care, and the patient all ultimately can lead to anunplanned readmission and by dissolution and realignment, as is illustrated in figure 15 vicious cycles are converted to virtuous cycles as illustrated in figure 16 . Virtuous cycles are developed between primary care involving communication and secondary care communication. Additional virtuous cycles involve treatment and medication compliance with personal wellness and involving a support system and a 3rd virtuous cycle identified, also involves primary care communication with key performance indicators, reduction of hospital and operational costs, simplification of hospital policy and procedures, which affect the patient in a positive manner. In summary, vicious cycles have been realigned and the dissolution process completed to reorganize and form virtuous cycles, (figure 17). Behind the virtuous cycles is the overall concept of patient care and overall wellness with a rapidly accumulated experience, rising process efficiency becomes better information and clinical data. This is then followed and implemented by more fully dedicated teams, more tailored services of facilities which leads to greater leverage in purchasing and rising capacity for sub specialization. This then allows to spread the cost of IT measurement and process improvement over a larger population i.e. a population health perspective. This becomes self-fulfilling leading to wider capabilities in the care cycle including patient education and engagement which then leads to faster

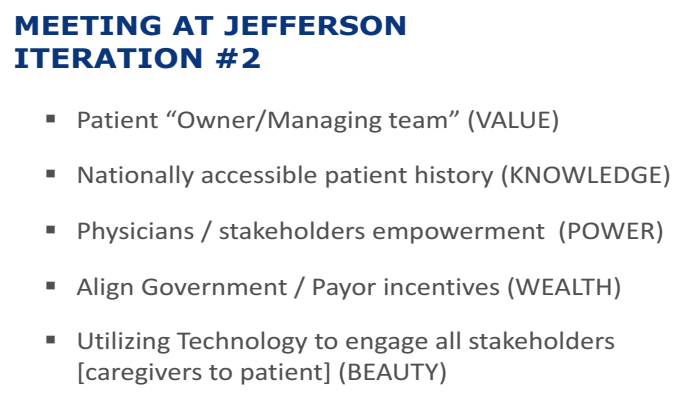

- Patient “Owner/Managing team” (VALUE)

- Nationally accessible patient history (KNOWLEDGE)

- Physicians / stakeholders empowerment (POWER)

- Align Government / Payor incentives (WEALTH)

- Utilizing Technology to engage all stakeholders [caregivers to patient] (BEAUTY)

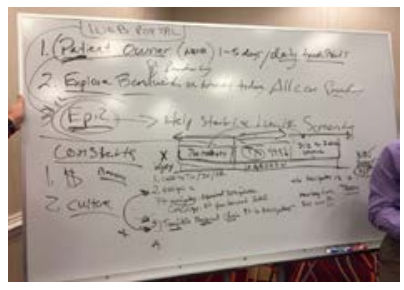

\section{Figure 12.}

\section{DESIGN TEAM'S IDEALIZED DESIGN ITERATION \#3}

- Develop a Patient Technology platform that provides all previous medical history, real time interactions from all touch points, and suggested treatment pathway

- Single Dedicated resource for all patients that move through the system

- Community of Care Network

\section{Iterate}

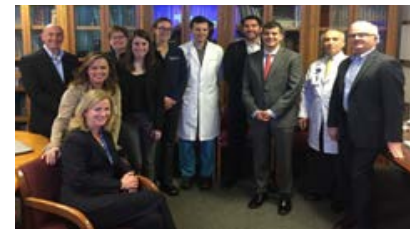

\section{Figure 13.}

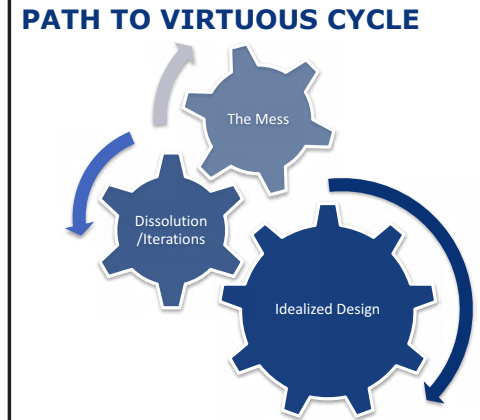

Figure 14.

innovation, better results adjusted for disease risk, improving reputation, which all have a positive feedback loop into patient care and overall wellness (Figure 17).

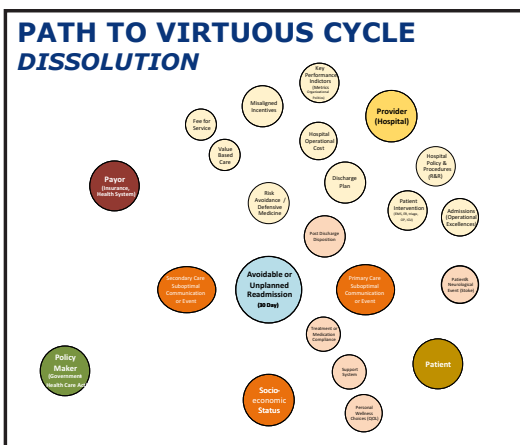

Figure 15

In looking forward, 3 virtuous cycles can certainly be identified. There may be additional ones, but improved patient experience, reduced cost, and improved population health are positive feedback loops as illustrated in figure 18. 


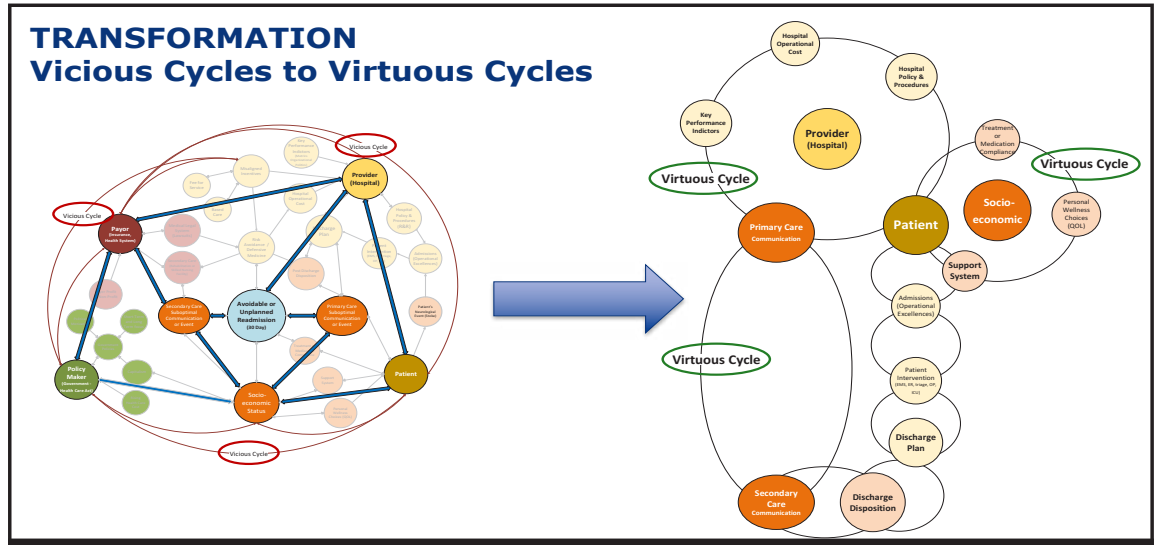

Figure 16.

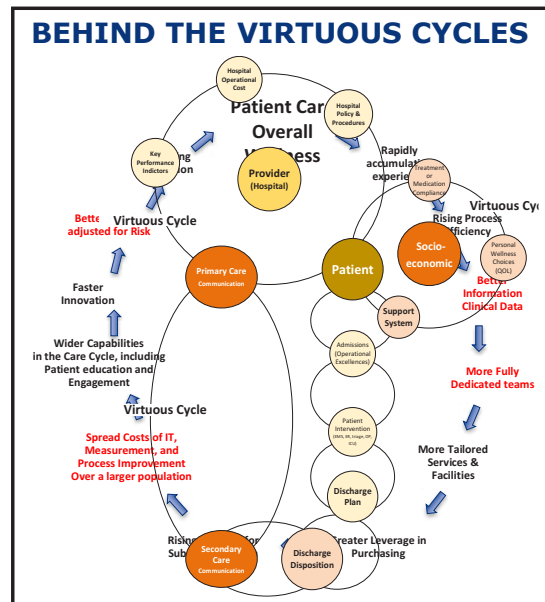

\section{Figure 17.}

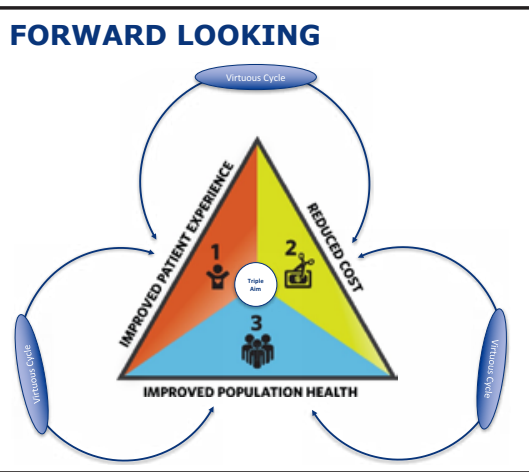

Figure 18.

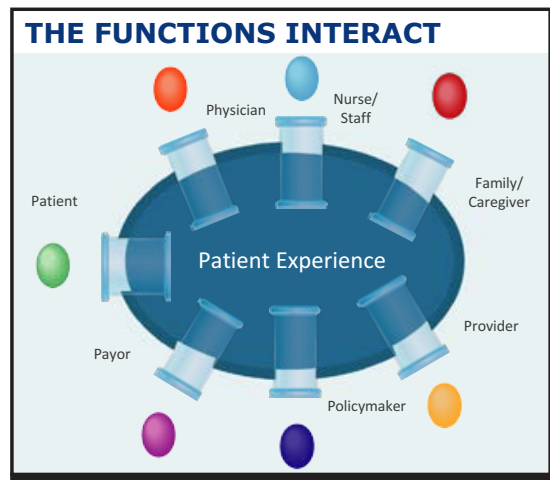

Figure 19.

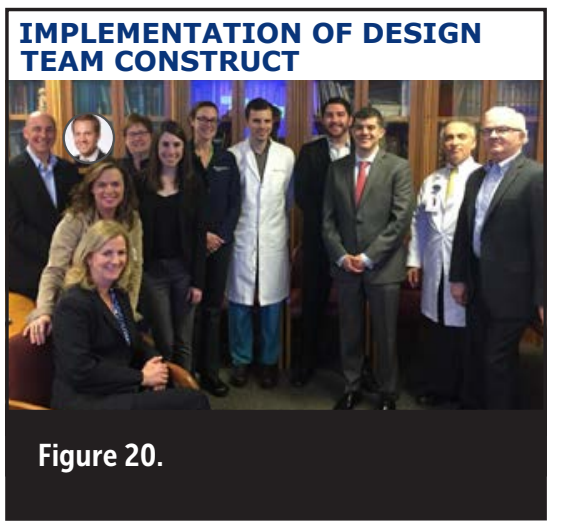

All of these functions interact (Figure 19). The 3 V's to sustainable success are taking a vicious cycle converting via dissolution to virtuous cycles which ultimately becomes a victorious situation, but it does not end here and the iterative processes must continue.

\section{CONCLUSION}

In summary, the tools of systems thinking were utilized to perform dissolution of an inadequate health care delivery system and to implement and design a new team construct. As William E. Demming is quoted, "managed care means managing the processes of care, not managing the physicians and nurses (Figure 20)."

\section{SOURCES}

Ackoff, R. L. 1967. Management misinformation systems. Management Science (December): B147-B156. (JSTOR link).

Ackoff, R. L. 1968. Toward an idealized university. Management Science (December): B121-B131. (JSTOR link).

Ackoff, R. L. 1993. From mechnanistic to social systemic thinking. Systems Thinking in Action Conference. (Link to Ackoff pdf file).

Ackoff, R. L. 1999. Ackoff's Best: His Classic Writings on Management. Wiley.

Ackoff, R. L., F. Emery and B. Ruben. 2005. On Purposeful Systems: An Interdisciplinary Analysis of Individual and Social Behavior as a System of Purposeful Events. Aldine Transaction.

Ackoff, R. L., H. J. Addison and J. Gharajedaghi. 2010. Systems Thinking for Curious Managers: With $40 \mathrm{New}$ Management f-Laws. Triarchy Press Ltd.

Ackoff, R. L., H. J. Addison and S. Bibb. 2007. Management f-Laws. Triarchy Press Ltd.

Baker, E. M. 1999. Scoring a Whole in One: People in Enterprise Playing in Concert (Best Management Practices). Crisp Publications. (Contents).

Barrett, D. 2007. Paradigm shifts for the twentyfirst century management science. Cost Management (November/December): 5-11.

Bateson, G. 1981. Paradigmatic conservatism. In Rigor \& Imagination: Essays from the Legacy of Gregory Bateson, edited by C. Wilder-Mott and J. H. Weakland. Praeger Publishers: 347-355.

Bateson, G. 1991. Sacred Unity: Further Steps to an Ecology of Mind. Harper Collins.

Bateson, G. 2000. Steps to an Ecology of Mind: Collected Essays in Anthropology, Psychiatry, Evolution, and Epistemology. University of Chicago Press. 
Bateson, G. 2002. Mind and Nature: A Necessary Unity (Advances in Systems Theory, Complexity, and the Human Sciences). Hampton Pr.

(Originally published in 1980).

Bellows, B. 2016. Out of the Blue - Come together and mind the choice. Lean Management Journal (February): 34-36. (Link to Bellows pdf Out of the Blue).

Bensaou, M. and M. Earl. 1998. The right mindset for managing information technology. Harvard Business Review (September-October): 119-128. (Summary).

Capra, F. 1997. The Web of Life: A New Scientific Understanding of Living Systems. Anchor.

Capra, F. 2004. The Hidden Connections: A Science for Sustainable Living. Anchor.

Carlson, A. E. 1967. Budgeting vs. total systems concept. Management Accounting (February): 52-54.

Castellano, J. F., S. Young and H. A. Roehm. 2002. Teaching business as a system. Management Accounting Quarterly (Summer): 1-5. (Summary).

Christopher, W. 2003. Systems structure \& system thinking for improving results in a world of change. Cost Management (July/August): 44-

Cohen, J. R. and L. L. Holder-Webb. 2006. Rethinking the influence of agency theory in the accounting academy. Issues in Accounting Education (February): 17-30.

De Geus, A. 1999. The living company. Harvard Business Review (March-April): 51-59. (Summary).

De Geus, A. 2002. The Living Company: Habits for Survival in a Turbulent Business Environment. Harvard Business School Press.

De Rosnay, J. 1979. The Macroscope: A New World Scientific System. Translated from French by Robert Edwards. Harper \& Row. (Link to the web edition).

Deming, W. E. 1986. Out of the Crisis. Cambridge: Massachusetts Institute of Technology Center for Advanced Engineering Study.

Deming, W. E. 1993. The New Economics for Industry, Government, Education. Cambridge: Massachusetts Institute of Technology Center for Advanced Engineering Study. (Summary).

Dror, Y. 1970. Systems analysis and national modernization decisions. The Academy of Management Journal 13(2): 139-152. (JSTOR link).

Duncan, D. M. 1972. James G. Miller's living systems theory: Issues for management thought and practice. The Academy of Management Journal 15(4): 513-523. (JSTOR link).

Ehrenfeld, J. 2004. Searching for sustainability: No quick fix. Reflections: The Sol Journal of Knowledge, Learning, and Change 5(8): 137-149.

Eppen, G. D. 1965. A dynamic analysis of a class of deteriorating systems. Management Science (November): 223-240. (JSTOR link).
Esquire. 2015. America: These are your choices. Esquire (December/January): 149-153, 160-161, 164,168 . (Summary - This is a summary of ten questions related to the most critical choices for America based on information from the Brookings Institution).

Feigenbaum, D. S. and M. W. Sasieni. 1968. The engineering and management of an effective system. Management Science (August): B721B732. (JSTOR link).

Flood, R. L. 1999. Rethinking the Fifth Discipline. Routledge.

Garvin, D. A., A. C. Edmondson and F. Gino. 2008. Is yours a learning organization? Harvard Business Review (March): 109-116.

Gharajedaghi, Jamshid, Systems Thinking, Third Edition: Managing Chaos and Complexity: A Platform for Designing Business Architecture 3rd Edition, Morgan Kaufmann; 3 edition (July 13, 2011)

Greenberg, P. S. 1997. Using a systems framework to develop higher level thinking skills in cost/ management accounting: Experimental evidence. Journal of Accounting Education 15(4): 559-575.

Harries-Jones, P. 1995. A Recursive Vision: Ecological Understanding and Gregory Bateson. University of Toronto Press.

Higgins, T. T. Not dated. Pratt \& Whitney Rocketdyne's A Thinking Roadmap. https://maaw.info/ArticleSummaries/ ArtSumHigginsThinkingRoadmap.htm

lansiti, M. and R. Levien. 2004. Strategy as ecology. Harvard Business Review (March): 68-78. (Summary).

Johnson, H. T. 1997. A different perspective on quality: Bringing management to life. Deming Electronic Network Keynote address. http:// deming.ces.clemson.edu/pub/den/deming_ johnson1.htm. (DEN link)

Johnson, H. T. 2004. Confronting the tyranny of management by numbers: How business can deliver the results we care about most. Reflections: The Sol Journal of Knowledge, Learning, and Change 5(4): 51-61.

Johnson, H. T. 2006. Lean accounting: To become lean, shed accounting. Cost Management (January/February): 6-17. (Summary).

Johnson, H. T. 2006. Sustainability and "Lean Operations". Cost Management (March/April): 40-45. (Summary).

Johnson, H. T. 2012. A global system growing itself to death - and what we can do about it. The Systems Thinker (May): 2-6. (Summary).

Johnson, H. T. 2014. Accounting, accountability, and misplaced concreteness. Process Studies. (Fall/Winter): 47-60. (Link to Johnson - Process Studies).

Johnson, H. T. and A. Broms. 2000. Profit Beyond Measure: Extraordinary Results through Attention to Work and People. New York: The Free Press. (Summary).
Johnson, R. A., F. E. Kast and J. E. Rosenzweig. 1964. Systems theory and management. Management Science (January): 367-384. (JSTOR link).

Kast, F. E. and J. E. Rosenzweig. 1972. General systems theory: Applications for organization and management. The Academy of Management Journal 15(4): 447-465. (JSTOR link).

Laszlo, E. 1996. The Systems View of the World: A Holistic Vision for Our Time (Advances in Systems Theory, Complexity, and the Human Sciences). Hampton Press

Lee, L. S. and E. Green. 2015. Systems thinking and its implications in enterprise risk management. Journal of Information Systems (Summer): 195-210.

Lynton, R. P. 1969. Linking an innovative subsystem into the system. Administrative Science Quarterly 14(3): 398-416. (JSTOR link).

Mantell, L. H. 1968. A note on systems theory and the idea of interface. The Academy of Management Journal 11(1): 126-128. (JSTOR link)

Martin, J. R. Not dated. Russell Ackoff quotes and f-laws. Management And Accounting Web. https://maaw.info/RussellAckoff.htm

Martin, J. R. Not dated. Russell Ackoff: What is a system? Videos. Management And Accounting Web. https://maaw.info/RussellAckoffVideos.htm

Martin, J. R. Not dated. The Beer Game. Management And Accounting Web. (Summary). Mattessich, R. 1982. The systems approach: Its variety of aspects. Journal of the American Society for Information Science33 (6): 383-394.

McClary, E. S. 1933. Accident prevention. N.A.C.A. Bulletin (March 1): 1007-1014.

Meadows, D. H. 2008. Thinking in Systems: A Primer. Chelsea Green Publishing

Mullin, R. F. 2006. Spotting quality: A quality management view. Decision Line (March): 19-26.

Page, B. 2013. Should we change the system or the process? Strategic Finance (November): 46-51.

Peery, N. S. Jr. 1972. General systems theory: An inquiry into its social philosophy. The Academy of Management Journal15 (4): 495-510. (JSTOR link).

Phillips, D. C. 1969. Systems theory - A discredited philosophy. Abacus 5(1): 3-15.

Phillips, D. C. 1972. The methodological basis of systems theory. The Academy of Management Journal 15(4): 469-477. (JSTOR link).

Pondy, L. R. 1966. A systems theory of organizational conflict. The Academy of Management Journal 9(3): 246-256. (JSTOR link).

Pourdehnad, J., E. R. Wexler and D. V. Wilson 2011. Integrating systems thinking and design thinking. Systems Thinker22 (9 November): 2-7. (Link to pdf file).

Ramage, M. and K. Shipp. 2009. Systems Thinkers. Springer 
Ratnatunga, J. and M. Ariff. 2005. Editorial: Towards a holistic model of corporate governance. Journal of Applied Management Accounting Research (Winter): 1-16.

Rieber, R. W. Editor. 2003. The Individual, Communication, and Society: Essays in Memory of Gregory Bateson. Cambridge University Press.

Schueler, R. H. 1974. The systems concept. Management Accounting (June): 33-34, 42.

Senge, P. M. 1990. The Fifth Discipline: The Art and Practice of the Learning Organization. New York, NY: Doubleday. (Summary).

Senge, P. M. 2008. The Necessary Revolution: How Individuals and Organisations are Working Together to Create a Sustainable World. Nicholas Brealey Publishing Ltd.

Senge, P. M., A. Kleiner, C. Roberts, G. Roth, R. Ross and B. Smith. 1999. The Dance of Change: The Challenges to Sustaining Momentum in Learning Organizations. Doubleday.

Senge, P. M., A. Kleiner, C. Roberts, R. Ross and B. Smith. 1994. The Fifth Discipline Fieldbook: Strategies and Tools for Building a Learning Organization. Crown Business.

Senge, P. M., B. B. Lichtenstein, K. Kaeufer, H. Bradbury and J. Carroll. 2007. Collaborating for systemic change. MIT Sloan Management Review (Winter): 44-53. (Cross-sector collaboration is needed to meet the sustainability challenge interweaving work in the conceptual, the relational, and the action-driven realms).
Senge, P. M., B. Smith, N. Kruschwitz, J. Laur and S. Schley. 2010. The Necessary Revolution: Working Together to Create a Sustainable World. Crown Business.

Senge, P. M., C. O. Scharmer, J. Jaworski and B. S. Flowers. 2004. Presence: Human Purpose and the Field of the Future. Sol.

Sharman, P. 2010. An interview with Eleanor Bloxham. Cost Management (July/August): 20-25. (Eleanor Bloxham, CEO of The Value Alliance, discusses some concepts from her book, Bloxham, E. 2003. From Economic Value Management: Applications and Techniques. John Wiley and Sons.).

Simonin, B. L. 1997. The importance of collaborative know-how: An empirical test of the learning organization. The Academy of Management Journal 40(5): 1150-1174. (JSTOR link).

Spear, S. and H. K. Bowen. 1999. Decoding the DNA of the Toyota production system. Harvard Business Review (September-October): 97-106. (Summary).

Steele, F. R. C. 1921. Limitations of system. Journal of Accountancy (January): 21-29.

Stimpert, J. L. and I. M. Duhaime. 1997. Seeing the big picture: The influence of industry, diversification, and business strategy on performance. The Academy of Management Journal 40(3): 560-583. (JSTOR link).
Swanson, G. A. 2006. A systems view of the environment of environmental accounting. Environmental Accounting: Commitment or Propaganda. Advances in Environmental Accounting \& Management (3): 169-193.

Sweeney, L. B. and D. Meadows. 2010. The Systems Thinking Playbook: Exercises to Stretch and Build Learning and Systems Thinking Capabilities. Chelsea Green Publishing.

Thayer, F. 1972. General system(s) theory: The promise that could not be kept. The Academy of Management Journal 15(4): 481-493. (JSTOR link).

Von Bertalanffy, L. 1972. The history and status of general systems theory. The Academy of Management Journal 15(4): 407-426. (JSTOR link).

Waddock, S. 2005. Hollow men and women at the helm ... Hollow accounting ethics? Issues in Accounting Education (May): 145-150. (Summary).

White, D. 1995. Application of systems thinking to risk management: A review of the literature. Management Decision33 (10): 35-45.

Wren, D. A. 1968. A note on systems theory and the idea of interface: Reply. The Academy of Management Journal 11(1): 128-129. (JSTOR link).

Zink, K. J. 1995. Total Quality Management as a Holistic Management Concept. Springer.

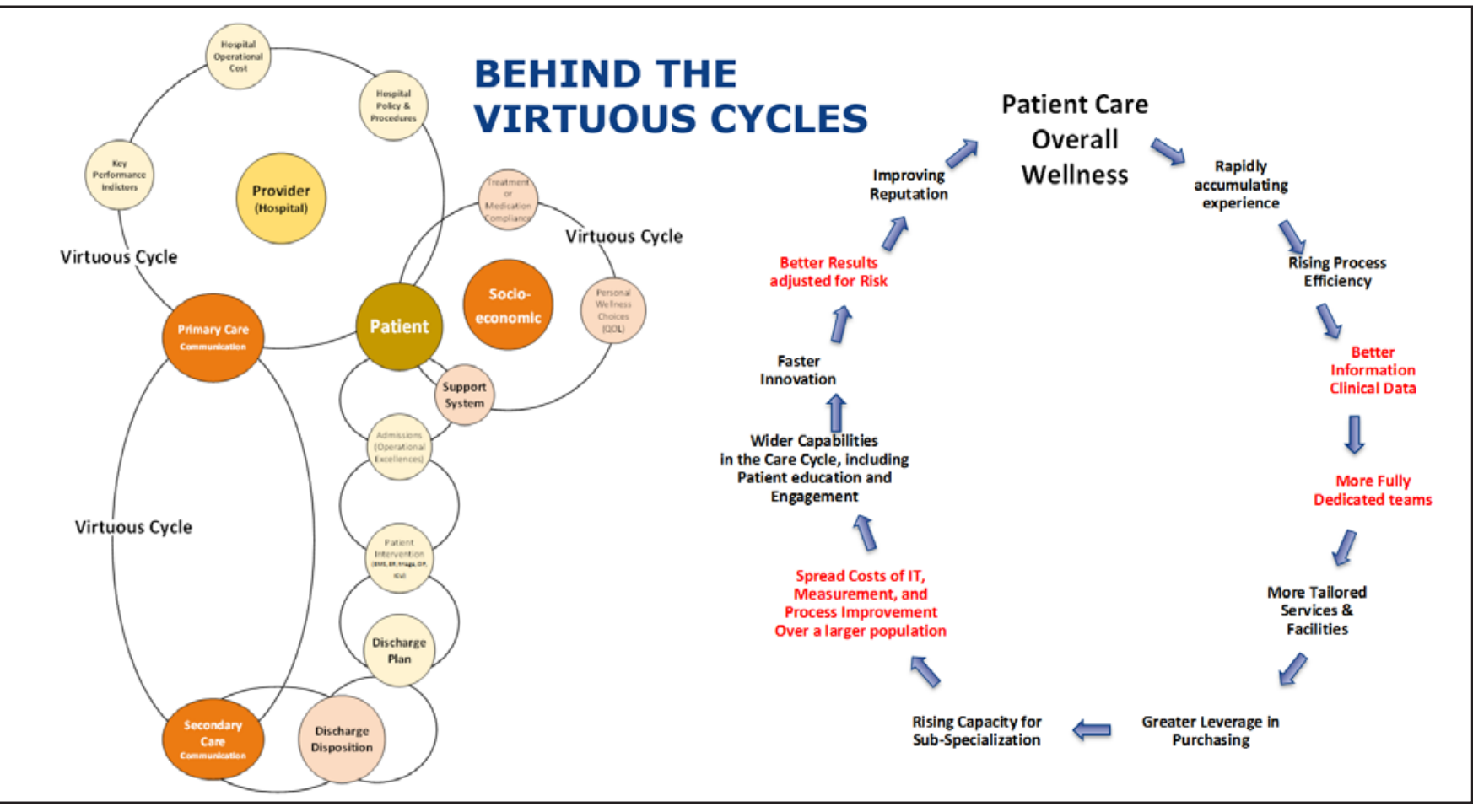

